Beata Siwek

Lublin

\title{
W świetlistości wszechprzenikającej, czyli Symbolika światła i słońca w poezji „Białowieża”
}

Wszelkie jubileusze, tym bardziej tak znaczące jak ten, 55-lecie Białoruskiego Stowarzyszenia Literackiego „Białowieża”, skłaniają do refleksji nad czasem minionym. W takiej chwili nie ma miejsca na rozpamiętywanie potknięć, ewentualnych porażek, na żale, że nie wszystko udało się zrealizować, że przepuściliśmy tyle szans. Jest to raczej czas sprzyjający pozytywnym refleksjom, podsumowaniom o charakterze wartościującym, czas wydobywania tego, co najcenniejsze. Zaledwie kilka lat temu poeta i animator wielu przedsięwzięć naukowych, wydawniczych i organizacyjnych, popularyzujących twórczość Białorusinów mieszkających w Polsce, Jan Czykwin, pisał:

Niemal pięćdziesiąt lat, które ma już za sobą Białoruskie Stowarzyszenie Literackie „Białowieża”, to szmat czasu. Do takiego długiego biegu, z natury chyba rzeczy, nie są przygotowane „organizmy” społeczne, rozpadają się one o wiele wcześniej. Fenomen „Białowieży” jednak trwa i to trwanie prowokuje do stawiania dziś pytań, przynajmniej takich oto: dlaczego w Polsce rozwinęła się mimo wszystko tylko białoruska literatura, dlaczego nie zatrzymała się tylko ona (lub nie zatrzymano jej) na poziomie ludowości, w czym wreszcie wyraża się jej zasadnicza inność, niepowtarzalność? ${ }^{1}$

Pytania te dotyczą najistotniejszych, fundamentalnych zagadnień, bo w istocie zdumiewa fakt tak konsekwentnego dążenia „Białowieżan” do promowania rodzimej kultury i języka, zaskakuje niesamowita dojrzałość artystyczna poetów, czy wreszcie wyraźnie obecna w tej twórczości perspek-

1 J. Czykwin, Kości zostały rzucone, [w:] tegoż, Па прызванні і абавязку. Літаратурна-крытыичныя артылуль, Беласток 2005, s. 191. 
tywa humanistyczna, odkrywany wciąż na nowo świat ludzkich wartości: religijnych, etycznych, estetycznych. W kręgu wpływów współczesnego nihilizmu samo słowo „wartość” jawi się jako relikt świata, który definitywnie przeminął, jednakże świata opromienionego światłem, blaskiem, aurą tajemniczości.

Wiele już lat temu polski historyk literatury Stefan Sawicki pisał: $O b$ cowanie z literatura umożliwia najpetniejszy kontakt z rzeczywistościa, najbardziej wszechstronne przekraczanie siebie i powrót, budujacy nasza tożsamość. Pamiętajmy o tym, gdy wkrada się w nas - „stugi nieużyteczne” poezji - zwatpienie, czy ważne jest to, co robimy, gdy aktywność świata bliższego $i$ dalszego utrudnia zachowanie wierności temu, cośmy świadomie wybrali, co jest słabiej dostrzegalne, mniej doraźnie konieczne, ale przecież $i$ trwalsze, $i$ glębsze $e^{2}$ Mam nadzieję, że takich dylematów nie mają już dziś poeci Białowieży, bowiem ich wkład w rozwój literatury narodowej, białoruskiej jest nieoceniony.

Poszukując jakiejś formy teoretycznego ekwiwalentu dla migotliwego, granicznego statusu wielu tekstów „Białowieżan” stajemy w obliczu złożonego problemu. Jaki wybrać sposób na mówienie o dziełach nie popadając przy tym w całkowite zaufanie do konkretnego, technicznego metajęzyka, żeby nie zawierzyć nadto możliwości dostępu do ostatecznego sensu tekstów, który można by w krytycznej analizie wyjawić i objaśnić, jaki wreszcie podjąć temat, żeby odkryć w tej twórczości nowy wymiar, dotychczas jeszcze należycie nie spenetrowany. Przedmiotem mojej refleksji nie będą tematyczne dominanty poezji Białowieżan, lecz obszar tematyczny stosunkowo mało jeszcze poznany, aczkolwiek - jak podpowiada intuicja badawcza - niezwykle ważny. Będzie to mianowicie motyw światła i słońca oraz eksplikowane przezeń treści. W kontekście jubileuszu wybór takiego właśnie motywu do poetyckiej eksploracji wydaje się jak najbardziej zasadny.

Jak zauważa polska badaczka Anna Krajewska, zarówno w refleksji literaturoznawczej, jak i filozoficznej istnieje grupa metafor, związanych ze światłem, wykorzystywanych na oddanie sensu zagadnień epistemologicznych. Jako przykład podaje tu „cienie w jaskini” Platona, „światło oświecenia”, „zwierciadło i lampa” (Meyer Howard Abrams), „płomień i świeca” (Gaston Bachelard), „przedświt” (Martin Heidegger), „lśnienie” jako odblask lustra (Umberto Eco, Jacques Lacan), ,światło zastane” (Clifford Geertz). Badaczka zauważa, że światło uczestniczy w określeniu stanu świata. Bez światła nie moglibyśmy zobaczyć świata i zdaje się niemal, że bez światła

\footnotetext{
2 S. Sawicki, Czym jest poezja?, [w:] tegoż, Wartość - Sacrum - Norwid, s. 17.
} 
wręcz nie byłoby świata ${ }^{3}$. Do powyższych rozważań można by dodać jeszcze stwierdzenie, że światło określa też człowieka, jest metaforą ludzkich pragnień, emocji, wzruszeń, nadziei. Jest eksplikacją wartości. Jest wreszcie jak podkreśla Dorothea Forstner - jako najbardziej niematerialne zjawisko całego stworzenia, szczególnie odpowiednim symbolem duchowości Boga ${ }^{4}$. Forstner zauważa ponadto, że chociaż słońca nie można utożsamiać ze światłem, to jednak zachodzi bardzo ścisły związek między symboliką światła i symboliką słońca ${ }^{5}$. Z tego też względu nie ominiemy naszą uwagą tych tekstów, w których obydwa motywy pojawiają się równolegle, bądź też jeden wyznacza drugi.

Warto przypomnieć, że w kosmogoniach większości ludów proces powstawania świata jest związany ze stawaniem się światła, przy czym światło - jak konstatuje Manfred Lurker - może pojawiać się po raz pierwszy w różny sposób: przez narodzenie, emanację, przez czynność albo też słowo bóstwa lub Boga ${ }^{6}$. Lurker, nawiązując do biblijnej relacji o stworzeniu świata przypomina, że na uwage zasługuje pierwsza ocena Boga, według którego światło jest dobre. Znana jest też powszechnie teoria logosu świata, do której nawiązuje jeden z autorów Nowego Testamentu, Jan, w prologu Ewangelii: Na początku było Stowo. Zarówno w obszarze myśli teologicznej, jak i filozoficznej światłość i słowo współzawodniczą o prymat w biblijnym obrazie początków świata.

Zarysowana po krótce perspektywa teoretyczna odnosząca się do symboliki światła, będzie dla nas punktem wyjścia dla refleksji o sposobach uobecniania się światła i jego zakresie semantycznym w poezji „Białowieża". Z racji ograniczonych możliwości artykułu ograniczę się tu do twórczości trzech poetów, u których motyw ten odgrywa znaczącą rolę, a mianowicie do poezji Jana Czykwina, Alesia Barskiego i Nadziei Artymowicz. Zarówno $\mathrm{w}$ aspekcie formalnym, jak i tematycznym twórczość wymienionych poetów stanowi jakości różnorodne, jednakże w perspektywie interesującego nas zagadnienia daje się wyłonić pewne cechy wspólne, odnaleźć punkt styczny.

Twórczość „Białowieżan” dowodzi ze wszech miar, że bieg ludzkiego życia, począwszy od narodzin, okresu dzieciństwa i młodości, wieku dojrzałego i starości można przedstawić przy pomocy obrazów kształtujących się

3 A. Krajewska, Światto jako metafora epistemologiczna, [w:] tejże, Dramatyczna teoria literatury. Zarys problematyki, Poznań 2009, s. 196.

4 D. Forstner OSB, Świat symboliki chrześcijańskiej. Leksykon, przeł. W. Zakrzewska, P. Pachciarek, R. Turzyński, Warszawa 2001, s. 92.

5 Tamże, s. 93.

6 M. Lurker, Przestanie symboli w mitach, kulturach i religiach, przeł. R. Wojnakowski, Warszawa 2011, s. 140. 
w oparciu o metaforykę świetlną. Poszczególnym okresom ludzkiego życia można by przyporządkować konkretne wyobrażenia związane z polem znaczeniowym światła. A zatem od światła, słońca, blasku, przez mroki, cienie, zmierzchy do światła, słońca, blasku. Ludzkie życie jest niczym innym, jak nieustannym dążeniem ku tej pierwotnej sile, która stała u podstaw kształtowania się świata. Jest bezgraniczną tęsknotą za blaskiem, ciepłem, jasnością, pewnością, którą ze sobą przynosi. W poetyckim ujęciu Jana Czykwina przyjmuje ono wyjątkowy kształt:

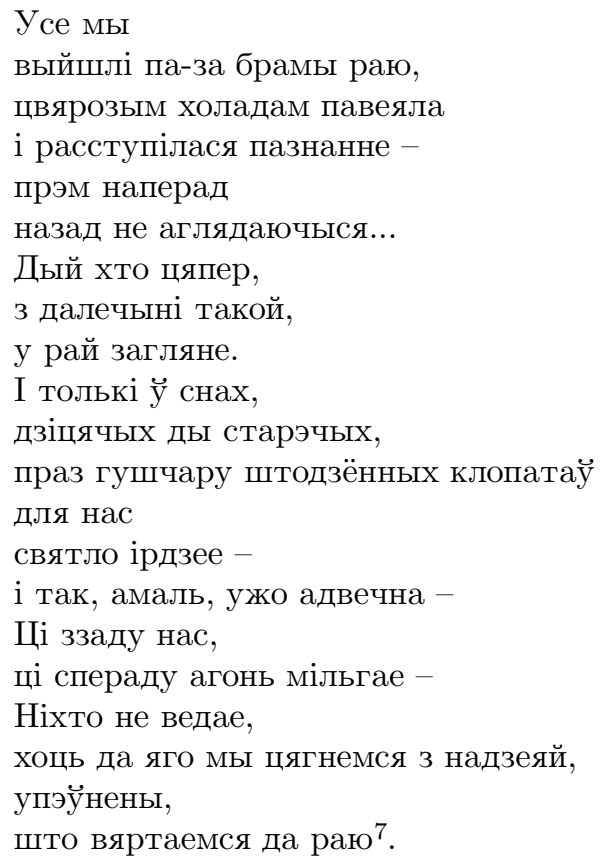

Doświadczana tu przez podmiot liryczny ciemność, utożsamiana z zagubieniem, zatraceniem pierwotnej wrażliwości, poprzedza nadejście światła. A zatem obszar ciemności poddany sile światła stopniowo ulega pomniejszeniu, wreszcie ustępuje. Motyw światła, symbolizujący dążność ku jedności wiecznego, idealnego, niezmiennego bytu odwołuje się tu do stanu onirycznego. Zaprezentowany utwór wskazuje na wpisane weń zjawisko gry semantycznej, a mianowicie, wyraz światło, a także jego synonimiczne określenia poeta wprowadza na różne aksjologiczne pola znaczeniowe. Można by zaryzykować stwierdzenie, że w poezji Czykwina zasada ta zmierza do

7 Я. Чыквін, ***Усе мы выйшлі..., [w:] tegoż, Адно жыциё. Выбранае, Беласток 2009 , s. 59. 
stworzenia pewnej jakości stylistycznej, u podstaw której leży intencja aksjologiczna. Świadczą o tym chociażby teksty ***Дзячінства за мною..., Даспелае сониа, ***Цяпер, калі разам, ***Маладыя гадзіны,, ${ }^{* *}$ Свет спахмурнеў, w których nieodmiennie światło uwikłane jest w sieć zależności o charakterze wartościującym i tym samym odsłania aksjologiczne wnętrze rzeczywistości. Nie ulega wątpliwości, że aksjologiczne odczytanie owych tekstów jest możliwe tylko i wyłącznie poprzez zbadanie relacji między podmiotem mówiącym i autorem a rzeczywistością przedstawioną $\mathrm{w}$ dziele ${ }^{8}$. W bogactwie zjawisk Czykwin szuka głębszego znaczenia, chce rozszyfrować tajemnicę, odnaleźć pierwiastek duchowy ukryty w materii i będący przyczyną wszystkiego, co jest dostrzegalne zmysłami. Należy jednak pamiętać, że to, co jest wartością, nie da się opisać dokładnie, tak jak inne cechy poznawanych przedmiotów. Jak podkreśla Stefan Sawicki, język nie posiada dostatecznie czułych znaczeń, które mogłyby posłużyć jako orzeczniki, nadążyć za indywidualnym charakterem zjawisk. W związku z tym skazani jesteśmy w tej dziedzinie na przybliżenia oparte na intuicji ${ }^{9}$. Niemniej jednak w języku poezji może się uobecniać w różnorodny sposób:

Я маладая, я - ў цвіценні,
Я прыгажэю з кожным днём.
Ва мне гарыць агонь агнём,
Начныя спеюць летуценні.
Іду - прасветлена, жывая,
Згартаючы красу ў букет,
Каб пераліць усю сябе у свет.
I цвердзь калышацца зямная.
І смерць хаваецца за небаскраем,--
Калі вяртаюся у рай!10

W poezji Jana Czykwina bardzo wyraźnie pobrzmiewa motyw światła przeświecającego przez „,szczeliny świata” (mistrzowsko wyzyskana choćby w malarstwie Friedricha). Przypomnijmy, że motyw ten ma już swoją długą tradycję poetycką. Po raz pierwszy, bodajże, został podjęty przez symbolistów i zastosowany dla opisu ich własnej estetyki. Jego naczelną zasadę Zenon Przesmycki ujmował tak:

8 Patrz na ten temat: S. Sawicki, Problematyka aksjologiczna w badaniach literackich, [w:] Problematyka aksjologiczna w nauce o literaturze, red. S. Sawicki, A. Tyszczyk, Lublin 1992, s. $95-110$.

9 S. Sawicki, Ku świadomej ocenie w badaniach literackich, [w:] tegoż, Wartość - sacrum - Norwid, s. 57.

10 Я. Чыквін, Вяртанне, [w:] tegoż, На беразе Дубіч Царкоўньх, Беласток 2010, s. 6 . 
jak w życiu nie mamy możności przyjrzeć się wewnętrznej, nieskończonej świata i człowieka istocie i musimy zadowolić się tymi oślepiającymi oko przebłyskami, które rozdzierają od czasu do czasu szare tło zmysłowej rzeczywistości, tak też i w poezji można tylko w ramy rzeczywistych i odpowiednich szczegółów zmysłowych oprawiać perspektywy nieskończoności, specjalnymi dotknięciami pędzla poetyckiego markować te ostatnie, kazać się ich domyślać duchowi zdolnego do marzenia czytelnika i tu i ówdzie tylko fosforycznym błyskiem droge ku głębiom ukrytym rozświetlać ${ }^{11}$.

W poezji Czykwina światło staje się metaforą powszechnie aprobowanego procesu dochodzenia do prawdy na drodze rozumowej. Posiada té̇ znaczenie głębsze, które może być odczytane przez pryzmat symboliki biblijnej:

Ноч у імгле і дзень у тумане -

ліхаманкавы вобраз падзей і мыслення, пераблытаны лёсы, людзі і звенні у кроплі жыцця, мне дараванай.

А наводдаль, здаецца, светлае кола быцця.

I па крузе тым светлым там ходзіць сам Хрыстос - там два сонцы мігцяць.

Я іду ўсцяж жыцця нібы злодзей ${ }^{12}$.

Niemało interesujących przykładów realizacji motywu światła i słońca odnajdujemy w liryce Alesia Barskiego, czego dowodzą m.in.: ***Я промнем сонечныл, ***У возеры бельм, ***Адну толькі маю зямлю, ***Схавалася сонца ў травьи, ***3 табой ісиі, ***Узнімаюся штодзень да сониа, ***Тут кожная сасна. Rozległa przestrzeń interpretacyjna wspomnianych tekstów odwołuje się nie tylko do duchowego aspektu natury, a zatem do sfery makrokosmosu, otwiera się bowiem jednocześnie na indywidualną sferę spirytualną. W ujęciu Barskiego człowiek złączony jest z przyrodą za pomocą światła, a zatem wpisuje się w harmonię świata. Człowiek w poezji Alesia Barskiego nie opisuje urody świata tylko i wyłącznie przez zmysły, ale wywodzi je także z dobra i mądrości kultury. Poetycki świat Alesia Barskiego to rzeczywistość zbudowana na antynomii światła i ciemności, wyznaczającej dualistyczny obraz świata. Jak czytamy w „Mitologii Białorusinów": Гэты канфлікт меў яўнае касмаганічнае зна-

11 Z. Przesmycki, Wstęp do „Wyboru pism dramatycznych” Maeterlincka. W: Polska krytyka literacka (1800-1918). Materiaty, t. 4, oprac. J. Z. Jakubowski. Warszawa 1959, s. $56-57$.

12 Я. Чыквін, Бемоль Сяднёва, [w:] tegoż, Адно жыциё, s. 218. 
чэнне, паколькі адзначаў пачатак дэструкиьі касмічнага - сакральнага ва ўсіх яго частках - светаладу, уваходжання Хаосу ў структуры Космасу. Так з'яуัляюица проиіпастаўленні добрага $і$ ліхога, святла $i$ чемрьл, дня $i$ ночьл, сакральнага $i$ прафаннага ды інш ${ }^{13}$. Dualizm ontologiczny niemal zawsze współistnieje w poezji Barskiego obok dualizmu antropologicznego, a zatem obrazowe metafory światła i cienia, będące odzwierciedleniem świata rzeczywistego odsyłają nas do świata ludzkiego, świata ludzkich uczuć, emocji, doznań. Ten emocjonalny opis świata, pejzażu daje obraz prywatnego stosunku do świata, poprzez wydobycie wrażeń, jakie miejsce wyzwala w podmiocie. Z miejsc, wobec których pojawia się formuła emocjonalna, człowiek układa własną geografię świata, mapę żywą dla podmiotu, kultury:

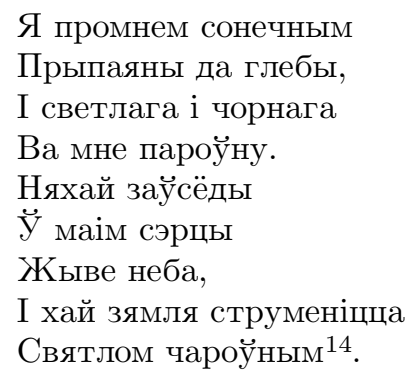

Symbolika światła i słońca w poezji Alesia Barskiego zwykle powiązana jest z refleksją antropologiczną dotyczącą sytuacji człowieka w świecie. Stąd różnorodne sposoby obrazowania przesycone są emblematami słonecznymi. Jednakże pomimo tego, że symbolika świetlna wyznacza w istocie kierunek interpretacji wielu motywów obrazowych i pojęciowych, w których przeważają aspekty pozytywne, to zwykle dopełniana jest ona przez symbolikę ciemności. Jednakże sugerowane przez nią aspekty negatywne nie zawsze pozostają ujemne, a raczej wydobywają nowy sens wizji ludzkiego bytu i losu. W tej wizji ciemność jest kontrastem dla pełnego blasku słońca:

Адкрыццяў больш
I больш таемнага на свеце,
Святло і цемра
У сужонстве вечным

13 Міфалогія беларусаў. Эниыєлапедычны слоўнік, склад. І. Клімковіч, В. Аўтушка, Мінск 2011, s. 455.

14 А. Барскі, ***Я промнем сонечныл, [w:] tegoż, Лірыцны пульс, Мінск 1987, s. 31.

15 А. Барскі, Дзевяноста трэияе, [w:] tegoż, Блізкасць далёкага, Беласток 1983, s. 99 . 
Także poetycki świat wyobraźni Nadziei Artymowicz jest pełen świateł, odblasków, światłocieni. Jednakże w wielu tekstach poetka przekracza granicę stonecznej metafizyki dla bardziej syntetycznego kształtu mistycznego doświadczenia ujętego w mroku. Oczywiście nie rezygnuje ze światła. Dąży jednakże do światła poprzez mrok. I dzięki temu „światło-noc” eliminuje pozorne sprzeczności. Autorka konsekwentnie ujawnia ich związek z poznawaniem świata, prowadząc do redukcji świata zewnętrznego, który nierzadko ujęty jest w kreowanej przestrzeni nadchodzącego końca świata. Charakterystyczna dla Artymowicz ambiwalencja, brak jednoznaczności w wykorzystaniu symboliki światła i nocy, słońca i mroku stwarza zupełnie nową jakość poetycką. Sensotwórcze zwątpienia nie pozwalają, co prawda, na osiągnięcie pełnej pewności, ale jednocześnie też nie przekreślają dążenia do niej. Światło prowadzi zwykle do duchowego przebudzenia, czy objawienia, posiada zatem jakość transcendentalną. Jego esencją jest prawdziwa iluminacja:

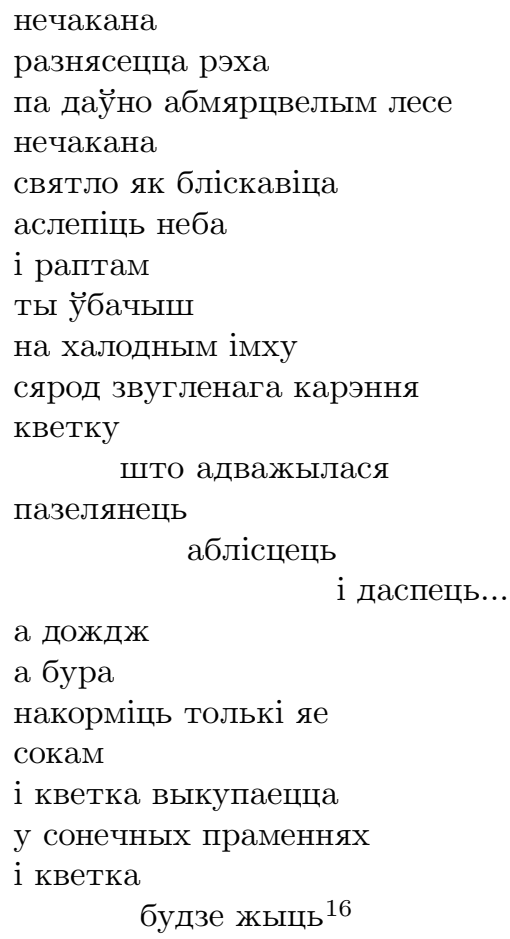

W poetyckim ujęciu Nadziei Artymowicz światło jest siłą ocalającą. Znamienne, że bezpośrednia ekspresja nastroju pociąga za sobą charaktery-

16 Н. Артымовіч, ***нечакана, [w:] tejże, Lagodny czas, Lublin 1998, s. 20. 
styczną analogię świata myśli i rzeczywistości zewnętrznej. Można by rzec, że ludzkie wnętrze, ukazane tu w metaforycznym ujęciu, przegląda się w obrazie rzeczywistości, a widzenie świata staje się kreacją wewnętrznego pejzażu duszy. Podmiot liryczny wierszy Nadziei Artymowicz trwa często uwięziony w nastroju i jednocześnie zatrzymany między dwoma odbijającymi się w sobie nawzajem światami. Poznawanie siebie prowadzi tu przez znaki zewnętrznego świata, czytanie świata to odnajdywanie w nim własnych myśli i nastrojów. Uwięzienie w nastroju, zamknięcie w świecie melancholijnego smutku, zatracanie się wartości oddaje autorka przez metaforyczny obraz śmierci słońca:

\author{
упаўшыя на зямлю без вачэй \\ адчуваюць боль пад жалезнай вопраткай \\ і паволі забываюць пра чыстыя бярозы \\ упаўшыя на зямлю не чакаюць хлебаноснай сенажаці \\ не разумеюць смерці сонца \\ не разумеюць дойгіх дажджой \\ не разумеюць вострай цішыні ${ }^{17}$
}

W poezji Nadziei Artymowicz stosunkowo często ze światłem połączona jest biel. Jest ona, jak podkreśla poetka, jak milczenie, które może być nagle zrozumiane, jak nadzieja, która czeka na swoje spełnienie. Zanikanie światła oznacza zatracanie się tego, co naznaczone wartością. Brak światła oznacza śmierć.

Przytoczone tu przykłady różnorodnych realizacji motywu światła i słońca, przyjmujących zwykle funkcję poetyckiego symbolu, pozwalają stwierdzić, że w istocie żywe symbolotwórstwo faktycznie przekracza horyzont ustanowiony przez praktykę literacką. Symbol w samej swej istocie nie korzysta z pewności sensu, jaka przysługuje słowu czy wizerunkowi. Sa to bowiem znaczenia powoływane w ramach dzieła, a ich sens kształtuje się w zderzeniu z konkretnym odbiorcą. Podsumowując należy podkreślić, że symbolika słoneczno-świetlna w poezji „Białowieżan” zaanektowana została przez wszystko to, co duchowe i boskie. Światło pełni zatem funkcje puryfikacyjną. Osobiste przeżycia mieszają się tu z historią, filozofią, świat fizyczny wiąże się organicznie ze światem psychicznym. Obecna w poezji „Białowieżan” symbolika poetycka, mistyczna, religijna, otwiera dostęp do tej sfery, która nie jest dostępna żadnym innym formom poznania, a kształtowana dzięki niej wyobraźnia symboliczna jest tą władzą człowieka, który

17 Н. Артымовіч, ***ynay̆шы на зямлю, [w:] tejże, Lagodny czas, s. 26. 
tworzy wszelki sens i znaczenia ${ }^{18}$. Wskazuje także na fakt nieustannego, uporczywego dążenia człowieka do uzyskania harmonii wewnętrznej i harmonii z otaczającym światem, do odnalezienia świata wartości transcendentnych:

$\mathrm{O}$, як чароўна на Зямлі

Усходзіць велічнае сонца!

I лёгка на душы, калі

Душы адкрыецца бясконцасць,

Калі тваёй душы

На сонцы сыплющца іскрынкі,

Калі так хораша $\ddot{y}$ цішы

I хочацца яе кранаць, як скрыпку.

I светлы дух у вышыні

Адзіны сцеле шлях абоім -

У тым свеце на Зямлі,

Дзе віяланчэль жыве $з$ габоем ${ }^{19}$.

\section{PЭЗ Ю $\mathrm{M}$}

Дадзены артыкул прысвячаецца сімволіцы святла і сонца ў творчасці паэтаў Беларускага літаратурнага аб'яднання "Белавежа" - Алеся Барскага, Яна Чыквіна і Надзеі Артымовіч. Ад тэарэтычных вывадай, што адносяцца да сімволікі святла, аўтар артыкула пераходзіць да аналізу выбраных паэтычных твораў, на аснове якіх свярджае, што сонечна-светлая сімволіка ў паэзіі «белавежцаў» амаль заўсёды звязана з тым, што духоўнае і боскае. Асабістыя перажыванні пераплятаюцца звычайна з гісторыяй і філасофіяй, а фізічны свет арганічна звязаны са светам псіхічным.

Ключавыя словы: святло, сонца, паэзія, сімвал, чалавек, душа.

\section{S U M M A R Y}

THE SYMBOLISM OF THE LIGHT AND SUN IN THE POETRY OF BELARUSIAN LITERARY ASSOCIATION "BELAVEZHA"

This article is about the symbolism of the Light and Sun in the poetry of Aleś Barski, Jan Czykwin and Nadzieja Artymowicz, who belong to the Belarusian Literary Association "Belavezha". From theoretical arguments the author proceeds to the analysis of selected poems, and concludes that symbolism of the Light and Sun in this poetry is almost always associated with the spiritual and divine. Personal experience is linked with the history and philosophy whereas the physical world is connected with the spiritual world.

Key words: light, sun, poetry, symbol, man, soul.

18 Por.: G. Durand, Wyobraźnia symboliczna, przeł. C. Rowiński, Warszawa 1986, s. 74.

19 Я. Чыквін, Вяртанне, [w:] tegoż, На беразе Дубіч Царкойных, s. 26. 